\title{
SOCIJALNI RAD I LOGIKA SIGURNOSTI U ERI SEKURITIZACIJE TERORIZMA
}

\section{Mirko Bilandžić}

Filozofski fakultet

Sveučilište u Zagrebu

E-mail: mbilandz@ffzg.hr

\author{
Josip Pandžić \\ Pravni fakultet \\ Sveučilište u Zagrebu \\ E-mail: josip.pandzic@pravo.hr
}

DOI: 10.20901/an.16.08
Pregledni rad
Prihvaćeno: srpanj 2019.

\begin{abstract}
Sažetak Socijalni rad usmjeren je k poboljšanju kvalitete života i razvoju potencijala pojedinaca, posebice ranjivih osoba, uz adresiranje problema, rizika, nepravdi i nejednakosti u društvu. Načela ljudskih prava i socijalne pravde čine temelje socijalnog rada. $U$ eri sekuritizacije terorizma od početka 21 . stoljeća zbog sve veće višedimenzionalnosti terorizma preklapaju se i umrežavaju različite politike, procesi i akteri te postupno nestaju granice između socijalnih i sigurnosnih provedbenih politika. Pomak od funkcije profesionalne skrbi ranjivih društvenih skupina k funkciji "nadzora" pojedinaca u interesu očuvanja društvenog poretka i sigurnosti daje socijalnom radu drugačiju ulogu. Socijalne službe i socijalni rad u protuterorističkim djelovanjima postaju podređeni logici sigurnosti. Na temelju analize okvira za uvođenje socijalnog rada u protuteroristički status i uloge socijalnih službi u protuterorizmu autori zaključuju da socijalni rad obavlja funkciju obavještajnog instrumenta nacionalne sigurnosti u protuterorističkim strategijama zapadnih demokracija.
\end{abstract}

Ključne riječi socijalni rad, socijalne službe, sekuritizacija, protuterorizam, nacionalna sigurnost

\section{Uvod: o logici sigurnosti}

Kao pojam polisemičnog karaktera, sigurnost je predmet izučavanja sigurnosnih studija. Nastanak i razvoj sigurnosnih studija Buzan i Hansen (2009) prikazali su u izvrsnoj knjizi The Evolution of International Security Studies, prvoj knjizi o intelektualnoj povijesti tog fenomena. Sigurnost kao središnji koncept sigurnosnih studija nema općeprihvaćeno određenje i značenje, među ostalim i zato što je to bitno politiziran koncept. Osim koncepcijske, sigurnosne studije obilježavaju normativni i empirijski prijepori. Takvo se stanje sažima u pitanjima što znače studije sigurnosti i što one uključuju (Collins 2010). Studije sigurnosti liminalnog su karaktera, granice im nisu čvrsto određene, postoje mnoge njihove "granične zone" $s$ drugim znanstvenim disciplinama, pa se epistemologija, teorije i metode tih disciplina koriste i u studijama sigurnosti (Bourbeau 2015). 
Kako je sigurnost socijalno konstruirana, različiti akteri pridaju joj različita značenja (Malik 2015), pri čemu se sadržaj pojma sigurnosti mijenja u različitima povijesnim kontekstima (Williams 2008). U objektivnom smislu, ona mjeri odsutnost prijetnji stečenim vrijednostima, a u subjektivnom smislu, nepostojanje straha da će te vrijednosti biti ugrožene (Wolfers 1962). Sigurnost nije fiksan ili dispozicijski nego dinamičan i kompleksan proces. Nikad nije konačan i potpuno kompletiran proces, budući da se sigurnosne potrebe stalno produciraju i reproduciraju (Bourbeau 2015a). Društvenoznanstvena istraživanja razlikuju tri koncepta na koje se referira sigurnost: vrsta socijalne i političke prakse, način uživanja dobroga i "stanje postojanosti" (state of being) (Herington 2015). Bez obzira na esencijalnu prijepornost pojma sigurnosti, možda veći prijepor izaziva odgovor na pitanje: što znači biti siguran? U kritičkoj perspektivi ništa manje prijeporna nisu ni pitanja: kako se ostvaruje sigurnost, što karakterizira politiku i praksu sigurnosti te kakve su "nuspojave" koje praksa sigurnosti izaziva (Waever 2015). Polisemičnost pojma sigurnosti ukazuje na to da postoje dvije epistemologije sigurnosti: proučavanje sigurnosti kao stvarnoga objektivnog stanja i proučavanje sigurnosti kao diskursa i prakse. U subjektivnoj, socijalno konstruiranoj tradiciji, sigurnost se proučava kao područje diskursa i prakse koji se razumiju u posebnom kontekstu i u određenome povijesnom trenutku (Stampnitzky i Mattson 2015). Konstruktivisti shvaćaju sigurnost kao projekt konstrukcije, nešto što postaje, a ne nešto što postoji. Sigurnost nije binaran model (siguran-nesiguran) nego buduće stanje koje se kontinuirano ostvaruje posredstvom upravljanja rizicima i rutinske prakse nadzora, što učvršćuje svakodnevnu sveprisutnost sigurnosti (Bourbeau, Balzacq i Cavelty 2015). To je okvir protuterorističkih strategija i politika nacionalnih država i međunarodne zajednice 21. stoljeća kojima je, kako pokazuju analize sadržaja i diskursa, zajednička nit sekuritizacija terorizma.

Sekuritizacija je koncept koji ukazuje na pokušaj objašnjenja i shvaćanja sigurnosti kroz socijalno i politički konstruiran proces posredstvom diskurzivne prakse socijalnih agenata (Waever 2011; Theiler 2010). Prema Van Munsteru (2005), retorička struktura akta sekuritizacije sastoji se od triju elemenata: (a) egzistencijalne prijetnje opstojnosti nekom objektu, (b) koja zahtijeva poduzimanje posebnih mjera radi zaštite i sigurnosti objekta koji je izložen prijetnji, (c) čime se opravdava i legitimira "kršenje" redovnih demokratskih postupaka odlučivanja. Širenje represivnih državnih ovlasti i uvođenje "stanja izuzetka" (state of exception) ili izvanrednog stanja (state of emergency) kao odgovora na terorističke prijetnje u redefiniranima sigurnosnim uvjetima postali su trajnom normom (Agamben 2008). To je bitno utjecalo na političku zajednicu i državne funkcije, a time i na funkciju i ulogu socijalnog rada i službi.

Suvremeno određenje sigurnosti i područje sigurnosnih studija značajno su prošireni te uključuju vojno, političko, socijetalno, gospodarsko i ekološko područje (Buzan 1991). Unatoč značajnu proširenju, područje socijalne sigurnosti ostalo je izvan interesa sigurnosnih studija i politike protuterorizma posebno i nacionalne sigurnosti općenito. Ozbiljnije znanstveno preispitivanje uključenja socijalne sigurnosti u okvire nacionalne sigurnosti gotovo je potpuno izostalo. Autori utjecajnih fundamentalnih radova otvoreno ističu da socijalnu sigurnost treba isključiti iz analitičkih okvira nacionalne i međunarodne sigurnosti (Buzan, Waever i De Wilde 1998; Buzan i Hansen 2009). Prema njihovu mišljenju, socijalna sigurnost 
nije "sigurnosno područje" te nije riječ o primjerenoj i podesnoj uporabi riječi sigurnost, nego o konceptima koji imaju semantičke sličnosti sa "sigurnošću". To obrazlažu tvrdnjom da se način operacionalizacije i značenje sigurnosti na području socijalne sigurnosti razlikuju od operacionalizacije na području nacionalne i međunarodne sigurnosti, pri čemu socijalna sigurnost ponajprije uključuje pitanja socijalne pravde i onoga na što pojedinci polažu prava. Stajališta o kvalitativnoj različitosti i analitičkoj djeljivosti socijalne sigurnosti te isključenju jednoga oblika sigurnosti (socijalne) iz analitičkog interesa drugoga oblika (nacionalne) niz je autora u svojima teorijskim i empirijskim studijama podvrgnuo kritici te izložio argumente prema kojima koncept socijalne sigurnosti nije samo stanovita povijesna preteča nacionalne sigurnosti, nego i da su ta dva pojma analitički i empirijski povezana, pri čemu obilje suvremene empirije, posebno na protuterorističkom području, ukazuje na potrebu preispitivanja uključivanja socijalne sigurnosti u sigurnosne studije (Bilandžić 2017).

U ovome radu iznosimo dodatne argumente u prilog tima kritičkim stajalištima. Cilj je rada analizirati okvir za priznavanje socijalnom radu statusa protuterorističkog instrumenta i transformacije uloge socijalnih službi kao aktera protuterorizma. Utječu li političko-sigurnosno okružje i terorizam kao oblik političkog nasilja na društvenu ulogu i profesionalnu funkciju socijalnog rada? Ovisi li socijalni rad kao element javne socijalne politike o funkciji sigurnosti? Kako sigurnost utječe na politiku i praksu socijalnog rada? Temeljna teza ovog rada glasi: zbog sve veće multidimenzionalnosti terorizma dolazi do preklapanja i umrežavanja različitih politika, procesa i aktera, te se granice između socijalnih i sigurnosnih provedbenih politika postupno brišu tako što se socijalni rad i službe koje se njime bave podređuju logici sigurnosti kroz protuterorističko djelovanje u eri sekuritizacije terorizma.

\section{Pojmovno-kategorijalna analiza}

\section{Socijalni rad}

Socijalni rad na stanovit je način "kišobranski koncept", a ne generički određen i analitički samodostatan pojam. Sintagma "socijalni rad" ima višestruka značenja: polje aktivnosti, profesionalnu domenu, visokospecijaliziranu profesiju, zajedničko polje društvenog djelovanja, socijalne teorije i istraživanja $u$ socijalnom radu ili korpus znanja socijalnog rada (Ewijk 2009: 61-62). Zbog svoje kompleksnosti, socijalni rad oduvijek je bio problematično definirati. To uključuje rad u različitom broju sektora (javni, privatni, neovisni, dobrovoljni), mnoštvu različitih okruženja (domovi, uredi, projekti razvoja zajednice), s radnicima koji preuzimaju različite zadatke (skrb, kontrola, osnaživanje, vođenje kampanje, procjenjivanje, upravljanje) i imaju različite svrhe (preraspodjela resursa potrebitima, socijalna kontrola i rehabilitacija devijantnih osoba, prevencija, smanjenje socijalnih problema) (Banks 1995: 1). Ciljevi su socijalnog rada čuvanje dostojanstva pojedinaca, razvijanje njihovih sposobnosti, unapređenje interpersonalnih odnosa te rješavanje socijalnih problema, pri čemu je pretežno usmjeren na socijalno ranjive skupine i pojedince. Socijalnim se radom aktiviraju resursi društvene zajednice, kao i njezina sposobnost za prevladavanje socijalnih problema (Bežovan, Matković, Puljiz, Šućur i Zrinščak 2005: 463-464).

Socijalni je rad državno organiziran i financiran sustav raspodjele dobara i usluga radi podmirivanja određenih socijalnih potreba pojedinaca, obitelji, skupina i zajednica, te "izlječenja", 
obuzdavanja ili kontrole ponašanja koje se smatra socijalno problematičnim ili devijantnim. Vodi se četirima načelima: (a) poštivanje i promicanje prava pojedinaca na samoodređenje, (b) promicanje dobrobiti, (c) jednakost, (d) distributivna pravda (Banks 1995: 17, 42; Barsky 2010: 3-5). Socijalna politika u tom je smislu krovni javnopolitički pojam s vidljivom sadržajnom dimenzijom na području prevladavanja socijalnih rizika i ostvarenja socijalne dobrobiti (Bilandžić 2017: 347), dok socijalni rad predstavlja korpus provedbenih politika čije mjere primjenjuju "socijalne službe". Kovanica je uvriježena ponajprije u anglosaksonskim državama, a riječ je o relativno velikom broju područja i zanimanja (Garner 2008: 31-35; Ritter i Vakalahi 2015), iako najopćenitije odgovara svim javnim službama koje se bave nekom vrstom socijalnog rada. ${ }^{1}$

Prema etičkom kodeksu američke Nacionalne udruge socijalnih radnika (NASW), povijesna i definirajuća odlika socijalnog rada jest fokusiranje profesije na dobrobiti pojedinaca u određenome društvenom kontekstu i na dobrobiti društva. Temeljni je čimbenik socijalnog rada obraćanje pažnje na okolišne sile koje stvaraju, pridonose i naslovljavaju probleme življenja (NASW 2008). Prema definiciji Međunarodne federacije socijalnih radnika (IFSW), riječ je o profesiji utemeljenoj na praksi i akademskoj disciplini koja promovira društvenu promjenu i razvoj, socijalnu koheziju, osnaživanje i oslobođenje ljudi. Vođena načelima socijalne pravde, ljudskih prava, kolektivne odgovornosti i poštivanja različitosti, ta profesija an-

Nasuprot, primjerice, Ujedinjenom Kraljevstvu gdje se u "socijalne službe" mogu svrstati i škole i zdravstvene ustanove sukladno mješovitom karakteru socijalnih usluga koje daju, u hrvatskom se slučaju područja djelovanja socijalnih službi odnose na organizirano pružanje različitih oblika socijalne skrbi u užem smislu. gažira ljude i strukture kako bi naslovili životne izazove i poboljšali dobrobit (IFSW 2014). Sukladno proklamiranim načelima krovnih profesionalnih organizacija, socijalni je rad institucionaliziran u različitim službama, isključivo je usmjeren ka ostvarivanju dobrobiti pojedinaca i društvenih skupina, ali je njegova praktična uloga oduvijek bila u mnogim aspektima kontrolna (Day 1979; Evens 1973).

Situacijski kontekst, neodređenost pojma i kompleksnost aktivnosti čine okvir koji generira "konflikte uloga" socijalnih radnika, budući da se profesija nalazi u svojevrsnom "rascjepu zahtjeva" između uloge "profesionalnog skrbnika" koji uživa povjerenje potrebitog korisnika i "nadzornika" koji kontrolira ljude u interesu zaštite postojećega društvenog poretka (Banks 1995). U društvenom kontekstu suočavanja s rizicima ističu se dvije orijentacije socijalnog rada: orijentacija na rizik i orijentacija na dobrobit (Parrott 2010: 92). U analizi rizika u socijalnom radu razlikuju se također dvije kategorije: rizici koje pojedinac predstavlja za druge i rizici kojima su pojedinci izloženi (ranjivost). Pritom, rizici iz prve kategorije podrazumijevaju nekoliko obilježja: (a) osobu koju se procjenjuje smatra se nositeljem rizika za druge, (b) rizik se definira kao štetno ponašanje, dok je šteta usmjerena na druge, (c) željeni ishod procjene rizika jest precizna identifikacija rizičnih osoba i njihovih mogućih ponašanja, (d) željeni je ishod upravljanja rizikom redukcija ili izbjegavanje rizika za druge, (e) prava i, do određene mjere, slobode nositelja rizika mogu biti ograničeni u interesu zaštite drugih ili prevencije budućih rizika (Kemshall 2013: 334). Situacijski kontekst sekuritizacije terorizma, uloga socijalnih službi kao "nadzornika" koji kontroliraju devijantna ponašanja u interesu društvenog poretka te orijentacija na pojedince i društvene grupacije 
koje predstavljaju sigurnosni rizik za društvo jesu niti kojima se socijalni rad vezuje za protuterorističko djelovanje.

\section{Protuterorizam}

Protuterorizam je u 21. stoljeću središnje pitanje međunarodne sigurnosti. Posebno je u suvremenim uvjetima terorizam stanovita, riječima Erlenbuscha (2014), "neprekinuta agonija". Unatoč opsežnome istraživačkom interesu, nema generičke definicije terorizma. Sociolozi koji proučavaju terorizam ukazuju na to da je terorizam otporan na "pročišćavanje" kako bi bio objekt znanja, pa je stoga riječ o konstruktu koji je u definiranju podložan moralnima i politiziranim aspektima (Stampnitzky 2015). Široka uporaba pojma terorizma u različitima povijesnim kontekstima nagnala je autore (Richards 2014) da se upitaju ima li taj pojam neko značenje, odnosno je li to pitanje "definicijska močvara". Ipak, višedesetljetna rigorozna akademska analiza i temeljita stručna ekspertiza doveli su do revidiranoga akademskog konsenzusa o definiciji terorizma (Schmid 2011: 76-83). Nova istraživanja, koja su pošla s jednakih metodoloških polazišta, koja uključuju analizu sadržaja i frekvencijsku analizu 373 raspoložive definicije terorizma, rezultirala su određenjem prema kojemu je terorizam organizirana uporaba sile i nasilja ili prijetnja uporabom nasilja kojom se posredstvom intencionalnog širenja straha odnosno terora, a na temelju anticipiranih širih psiholoških učinaka, nastoje ostvariti politički ciljevi (Lucić 2017: 89). Složenost terorizma upućuje na zaključak da pojedinačni uzroci i pristupi ne mogu potpuno objasniti terorizam. Svaki je "slučaj terorizama" jedinstven, to jest čini slučaj sui generis (Bjorgo 2005; Franks 2006; Richardson 2006). Objašnjenje i razumijevanje terorizma zahtijevaju objektivno znanje o društvenim odnosima koji ga proizvo- de. To je poseban izazov za protuterorističku strategiju i politiku.

Razmatrajući protuterorističko djelovanje, stručnjaci razlikuju antiterorizam (antiterrorism) i protuterorizam (counterterrorism), pri čemu je pojam protuterorizam preuzeo prvenstvo uključivši $\mathrm{u}$ sebe pojam antiterorizam. Antiterorizam naglasak stavlja na preventivne $i$ defenzivne mjere, dok protuterorizam uključuje proaktivne i "unaprijed preventivne" (preemptive) akcije usmjerene na prevenciju terorizma, odvraćanje od terorizma i aktivnu borbu protiv terorizma uporabom širokog spektra instrumenata: snaga reda i zakona, političkih, psihologijskih, socijalnih, ekonomskih i (para)vojnih. Protuterorističke strategije fokusirane su na: (a) uzroke terorizma (diskriminacija, deprivacija, politička represija, socijalne, političke i ekonomske nepravde, podjarmljivanja, nizak životni standard, to jest na sve ono što pogoduje nastanku i kadrovskom (pre) strukturiranju terorističkih organizacija); (b) sposobnosti terorističkih entiteta (reduciranje sposobnosti za izvršenje terorističkih akata); (3) namjere terorističkih entiteta (pravodobno raspolaganje točnim analizama namjera terorističkih organizacija i utjecaj na namjeravane akcije); (4) konkretne sigurnosne aktivnosti i protumjere (Bilandžić 2014).

Postoji li povezanost (protu)terorizma i socijalne politike te socijalnog rada? Analiza protuterorističkog kompleksa jasno upućuje na razloge povezanosti. Usmjerenost na prevenciju terorizma, uklanjanje uzroka terorizma i faktora koji vode $\mathrm{k}$ radikalizaciji i novačenju terorista razlozi su uključenja socijalnih službi u protuterorističke aktere. Točka dodira jest koncept deradikalizacije.

\section{Deradikalizacija i proturadikalizacija}

Politički diskurs o "nasilnom radikalizmu" postavio je koncept radikalizacije u središte studija terorizma i protuterori- 
stičkih politika (Schmid 2013). Kontroverzan i kompleksan pojam radikalizacije načelno podrazumijeva odmak od glavne struje političkog mišljenja, političkih i društvenih procesa. Khosrokhavar (2017) određuje radikalizaciju kao proces kojim pojedinac ili skupina usvaja nasilan oblik djelovanja koji je izravno sadržajno povezan s ekstremističkom ideologijom koja osporava postojeći poredak na političkome, društvenom ili kulturnom planu. Prema stručnjacima Europske komisije, radikalizacija je socijalizacija ka ekstremizmu koja se manifestira u terorizmu (Expert Group 2008). To uključuje promjene u mišljenjima, osjećajima i ponašanju pojedinaca i skupina, što rezultira usmjerenjem ka opravdanju međugrupnog nasilja i zahtijeva žrtvovanje za vlastitu društvenu skupinu ili zajednicu. Deradikalizacija i proturadikalizacija suprotnosti su radikalizaciji. Taj je pristup stanovit paradoks budući da deradikalizacija (odvraćanje od nasilja i društvena reintegracija radikaliziranih pojedinaca) $\mathrm{i}$ proturadikalizacija (socijalno i kulturno kontekstualna prevencija koja se poduzima kako netko ne bi postao radikalan) znače stanovito usmjerenje ka uzrocima terorizma. A to je područje do sada bilo zanemareno, gotovo ignorirano u znanstvenim istraživanjima i politikama djelovanjima spram terorizma. Programi deradikalizacije usmjereni su na sigurnosni aspekt (aktivni teroristi), a trebali bi rezultirati reintegracijom radikala $\mathrm{u}$ glavne društvene procese.

Proturadikalizacija je pak usmjerena na društvene aspekte koji bi trebali spriječiti sigurnosne ugroze, to jest terorizam. Radikalizacija je usmjerena na promjenu političkog sustava, pri čemu se koriste nasilna i nenasilna sredstva. To je istodobno top-down (autoriteti radikaliziraju pojedince i grupacije) $\mathrm{i}$ bottom-up proces (pojedinci i grupacije se samoradikaliziraju). Deradikalizacija (proturadikalizacija) se odnosi na programe kojima se radikalni pojedinci i skupine nastoje reintegrirati u društvo ili, u najmanju ruku, odvratiti od nasilja. Koncept deradikalizacije ima dva elementa: (a) mišljenje i stavove radikaliziranih pojedinaca i grupacija te (b) njihove akcije i ponašanje. Pritom, radikalizacija stavova ne znači i radikalno djelovanje: svaka radikalizirana osoba ne postaje terorist, kao što ni svaki terorist nema radikalne poglede. Strogo promatrano, deradikalizacija uključuje promjenu stajališta i vrijednosnih sudova (kognitivni aspekt) te bihevioralni aspekt, to jest promjene ponašanja kao konačan rezultat, odnosno odustajanje od preferiranja terorističkog djelovanja. Odustajanje od terorizma ne znači istodobno deradikalizaciju stavova, kao što ni deradikalizacija stavova ne znači odustajanje od terorizma. Empirijski je prijeporno i pitanje je li pojedina osoba prije unovačena u terorističku organizaciju pa potom radikalizirana ili obratno. S aspekta društva, važnija je promjena ponašanja radikaliziranih osoba (odustajanje od nasilja) nego promjena radikalnih stajališta, dok politički i sigurnosni aspekt ima drugačiji fokus. Nepromijenjena radikalna stajališta i uvjerenja vrlo brzo, naime, skliznu u terorizam (Schmid 2013; Horgan 2008; Horgan i Alteir 2012).

\section{Socijalni rad u funkciji protuterorizma}

Konstitutivan dio soocijalnog rada od njegova nastanka, u praktičnoj misiji, bili su i sigurnosni aspekti, u najmanju ruku u okviru koncepta ljudske sigurnosti koji je svojstven sigurnosnim studijama. Usmjerenost na dobrobit i ekonomsku sigurnost pojedinaca te uklanjanje različitih vrsta asocijalnih, devijantnih i nasilnih ponašanja samo su neka područja socijalnog rada koja sadržavaju sigurnosne aspekte i učinke. Sigurnosne aspekte 
nalazimo i u instrumentalizaciji socijalnog rada u političke svrhe. Povijesni primjer nacističke Njemačke, u kojoj su socijalni radnici slijedili instrukcije režima, a ne načela profesionalne etike, uvjerljiv je dokaz pogrešne postavke o mogućnosti razdvajanja profesionalnoga od političkoga sa smrtonosnim ishodima (Lorenz 1994). Pitanje sigurnosti u okvirima studija socijalne politike i socijalnog rada, bez obzira na semantičke prijepore, stvarno je bio predmetom i ranijih istraživanja u društvenim znanostima. Lociranje sigurnosne prakse u socijalnu politiku pronalazi se u funkciji socijalnog rada koja se odnosi na socijalnu kontrolu (Foucault 1977; Garland 2001). Također, $\mathrm{u}$ širem smislu, niz recentnih studija država (Izraela, Palestine, Sjeverne Irske) istražuje utjecaj političkog nasilja na socijalni rad (Ramon i sur. 2006; Campbell i McCrystal 2005; Baum i Ramon 2010) ili, konkretnije, utjecaj protuterorizma na socijalni rad, iznoseći niz argumenata koji upućuju na zaključak o sekuritizaciji socijalnog rada (Guru 2010; Ragazzi 2016; Sabir 2017; Cowden i Singh 2017; Choudhury 2017). Sustavan prikaz uloge profesionalnih socijalnih službi u okviru protuterorističkih djelovanja iznosi Abualola (2013) u studiji Social Services in the Field of Terrorism. Empirijske studije općenito i studije pojedinih država ukazuju i na ulogu socijalnih službi u protuterorističkom djelovanju i na rezultate utjecaja terorističkog djelovanja na socijalne radnike i profesionalne etičke dileme $\mathrm{u}$ protuterorističkom djelovanju (Itzhaky i York 2005; Ivanauskiene i Makštutyte 2012; Sweifach, LaPorte i Linzer 2010).

Razdvajanje funkcija profesionalnih skrbnika potrebitih i "nadzornika" koji kontroliraju ljude $\mathrm{u}$ interesu društvenog poretka određeno je povijesno i kontekstualno. Eskalacija terorizma na Zapadu uvjetovala je pomicanje naglaska na socijalnu kontrolu. Empirijska analiza vodila je k shvaćanju da je Zapad suo- čen s "domaćim", a ne s uvezenime islamističkim terorizmom (Mullins 2016). Suočavanje s tom činjenicom ujedno je značilo da su zapadne demokracije bile suočene $s$ radikalizacijom islamskih društvenih skupina. Upravo je pomak $\mathrm{k}$ prevenciji terorizma, odnosno deradikalizaciji i proturadikalizaciji, uvjetovao brisanje granica između socijalnih i sigurnosnih provedbenih politika te uvrštavanje socijalnog rada u okvire instrumenata nacionalne sigurnosti odnosno protuterorizma. Ako je radikalizacija proces koji se odvija u postupnim fazama, deradikalizacija je usmjerena na intervencije u taj proces kako bi se ranjive osobe spriječilo da postanu teroristi ili da podržavaju terorizam.

U studenom 2005. Vijeće Europske unije usvojilo je Protuterorističku strategiju Europske unije. Strategija se temelji na četiri kategorije aktivnosti: zaštiti od terorizma (Protection), prevenciji terorizma (Prevention), obavještajnom istraživanju usmjerenom na onemogućavanje izvršenja terorističkih akata i kazneno procesuiranje počinitelja terorističkih akata (Pursue) i odgovoru na izvršene terorističke akte, odnosno funkcioniranju u uvjetima krize kao posljedici izvršenja terorističkog akta (Respond). Premda je prevencija cijelo desetljeće jedan od četiriju stupova protuterorističkih strateških orijentacija, recentni teroristički udari u Europskoj uniji pokazali su da su ti pristupi nedostatni u sprečavanju terorizma te da je potrebno ojačati preventivne napore. Europska komisija je 2011. ustanovila "Mrežu za razvoj svijesti o radikalizaciji" (RAN) kao kišobransku mrežu koja povezuje profesionalce angažirane $u$ poslovima deradikalizacije. Uz policijske i pravosudne stručnjake, to uključuje i profesionalne aktere s područja koja tradicionalno nisu vezana za protuterorizam: nastavnike, predstavnike civilnog društva, lokalne vlasti. RAN-ovi centri 
za izvrsnost u tom kontekstu daju državama članicama logističku, tehničku i administrativnu podršku. Mreža je strukturirana prema tematskima radnim skupinama. Jedna od devet skupina jest Radna skupina za zdravstvenu i socijalnu skrb (Health and Social Care Working Group) kojoj je zadatak interpretirati znakove radikalizacije pojedinaca i grupacija te pomoći osobama koje su izložene riziku radikalizacije (Delivet 2016; RAN 2017). Kao jedan od triju prioritetnih sigurnosnih izazova Europske unije, pitanje deradikalizacije zauzelo je značajno mjesto i u Europskoj agendi sigurnosti. Socijalni rad opet je istaknut kao protuteroristički instrument.

Empirijska istraživanja provedena $\mathrm{u}$ Indoneziji, Pakistanu, Egiptu, Sjedinjenim Američkim Državama i Ujedinjenom Kraljevstvu utvrdila da su da su socijalni radnici, uz roditelje, nastavnike i religijske autoritete, najbolje pozicionirani s obzirom na mogućnosti identifikacije pojedinaca koji su izloženi i podložni riziku da se radikaliziraju, kao i na mogućnosti intervencije u slučaju radikalizacije (Mirahmadi 2016).

Ujedinjeno Kraljevstvo počelo je razvijati protuterorističku strategiju (CONTEST) odmah nakon islamističkog napada na Sjedinjene Države 2001. ${ }^{2}$ Izvorni tajni kabinetski dokument od devet stranica javnosti je postao dostupnim u prosincu 2006. (SACC 2016). Tom je strategijom stvoren okvir svih kasnijih, podrobno razrađenih, opsežnih strategija. ${ }^{3}$ Temelji se na četiri kategorije aktivnosti (4 $\left.P^{\prime} s\right)$ : (a) detekciji i obavje-

2 Opsežno navođenje primjera Ujedinjenog Kraljevstva izraz je veće relativne razvijenosti britanskih protuterorističkih politika u odnosu prema politikama većine drugih usporedivih država.

3 Dok prva strategija ima devet stranica, aktualna strategija iz 2011. napisana je na 125 stranica. štajnom istraživanju koji su usmjereni na onemogućavanje izvršenja terorističkih akata u najranijoj fazi, disrupciji terorističkih aktivnosti i kaznenom procesuiranju počinitelja terorističkih akata (Pursue); (b) prevenciji terorizma (Prevent) koja je ponajprije usmjerena na deradikalizaciju muslimanskih radikala; (c) zaštiti od terorizma (Protect) koja uključuje sigurnost granica, kritične infrastrukture, sigurnost javnih mjesta masovnog okupljanja i redukciju ranjivosti transportne mreže; (d) odgovoru na izvršene terorističke akte, odnosno ublažavanju posljedica terorizma i funkcioniranju u uvjetima krize kao posljedici izvršenja terorističkog akta (Prepare) (HM Government 2011).

Prevencija radikalizacije time je postavljena kao jedan od protuterorističkih prioriteta (Ragazzi 2016) i sastoji se od triju ciljeva: (a) odgovora na ideološke izazove terorizma i promociju terorizma, (b) sprečavanja skliznuća pojedinaca u terorizam, uz davanje odgovarajuće podrške i savjeta, (c) suradnje različitih profesionalnih sektora i područja (obrazovnih, vjerskih, karitativnih institucija i organizacija, policije, zdravstvene i socijalne skrbi, područja interneta) unutar kojih postoji rizik od radikalizacije (HM Government 2011; HM Government 2011a). Važnost prevencije dokazana je donošenjem zasebne Strategije za prevenciju (Prevent Strategy) 2011. Premda je Strategija usmjerena na sve tipove terorizma, očito je kako je u žarištu prevencije ponajprije muslimanska populacija. ${ }^{4}$

Empirijske studije protuterorističkih sektora i praksi europskih država ističu koncept "sumnjive zajednice" (suspect community) koji je primjenjiv na muslimansku zajednicu kao primarnu metu protuterorističkih mjera koje, zauzvrat, utječu na njezin identitet i stvaraju osjećaj zajedništva. Koncept se počeo razvijati početkom devedesetih godina prošlog stoljeća i vezuje se za Paddyja Hillyarda i njegovo istraživanje utjecaja britanskih protuterorističkih zakona i praksi u Sjevernoj Irskoj usmjerenih protiv 
Analizom Strategije uočava se da se radikalizacija smatra društvenim procesom, pri čemu je socijalna isključenost glavni uzrok radikalizacije. Širenje ekstremizma unutar muslimanskih zajednica povezano je sa segregacijom i diskriminacijom s kojima se suočavaju (Guru 2010). Lociranjem terorizma i procesa $\mathrm{u}$ kojemu netko postaje terorist u socijalnu isključenost, britanska se država očito usmjerila na depolitizaciju nadasve političkog fenomena, kakav je terorizam, te negiranje njegovih političkih uzroka. ${ }^{5}$ Uostalom, program za procjenu rizika (Vulnerability Assessment Framework, VAF), kao sastavni dio Strategije, koristi isključivo psihologijske indikatore rizika, ukupno dvadeset dva pokazatelja, a ne uključuje političke i socijetalne rizike, odnosno politički i socijetalni kontekst unutar kojega se radikalizacija događa (Knudsen 2018; HM Government 2012; HM Government 2015).

Nadalje, Svjetska organizacija za razvoj resursa i obrazovanje (WORDE), u "pristupu utemeljenom na zajednici" (community-based approach) radi suprotstavljanja nasilnom ekstremizmu, koristi "model klastera" kao okvir za analizu potecijalnog rizika od radikalizacije pojedinaca i njihova novačenja od strane ekstremističkih grupacija. Taj model svrstava faktore rizika u pet sku-

terorizma sjevernoirskih republikanaca. U recentnim uvjetima muslimanska zajednica zauzela je mjesto Iraca kao "sumnjive zajednice". O konceptu i njegovoj kritici $\mathrm{u}$ pogledu na primjenu na muslimansku zajednicu u Britaniji v. Ragazzi 2016a. Kritički osvrt primjene protuterorističkih mjera ponajprije na muslimansku zajednicu u državama Zapada v. Finch i McKendrick 2019; Kundani 2015; Awan 2012.

5 Pristupe utemeljene na depolitizaciji sekularnoga etnonacionalnog terorizma i tretiranja terorizma irskih republikanca kao kriminalnog čina britanska država primjenjivala je i u suvremenom sukobu s Irskom republikanskom armijom u Sjevernoj Irskoj (Bilandžić 2005). pina: (a) sociološki motivatori, (b) psihološki uvjeti, (c) ideologija, uvjerenja i vrijednosna orijentacija, (d) političko nezadovoljstvo i (e) ekonomski razlozi (Mirahmadi 2016). ${ }^{6}$ Prema strateškom određenju, da bi se suzbila radikalizacija, potrebno je razviti društvene programe za koheziju zajednice, harmonizaciju i integraciju, u čemu lokalne zajednice i vlasti imaju središnju ulogu, te ostvariti nadzor nad pojedincima za koje se utvrdi da su podložni riziku radikalizacije kako bi se deradikalizirali odnosno socijalno rehabilitirali. Polazi se od shvaćanja radikalizacije kao postupnog procesa unutar kojega je moguće identificirati posebne značajke i zajednička obilježja pojedinaca kao indikatore radikalizacije (Mythen, Walklate i Peatfield 2017). Za potrebe monitoringa rizičnih osoba uspostavljen je multiagencijski program za upravljanje rizicima s bazom podataka o radikaliziranim osobama. ${ }^{7}$ Njegov je cilj detektirati i identificirati pojedince koji su podložni riziku radikalizacije, procijeniti rizik moguće radikalizacije $\mathrm{i}$ dati im potporu kako ne bi postali teroristi odnosno podupiratelji terorizma (HM Government 2015). Akteri Channel programa su policija, lokalne vlasti, socijalna i zdravstvena služba, obrazovne i pravosudne institucije (HM Government 2011a; Ragazzi 2016). ${ }^{8}$ Strateška orijentacija postala je i zakonskom obvezom. Zakonom o sigurnosti i protuterorizmu (Counter-Terrorism and Security Act 2015) lokalnim je vlastima, a time i socijalnim službama, dana obveza djelovanja

6 Klasterski model sastavni je dio i američke protuterorističke politike (U.S. Department of Homeland Security 2016).

7 Službeni naziv incijative je "Okvir za procjenu ranjivosti" (Channel: Vulnerability assessment framework). U bazi podataka do 2018. bilo je 7.318 osoba koje su detektirane kao mogući teroristi (Home Office 2018).

8 Strategijom nisu određene praktične i etičke orijenatacije djelovanja. Emiprijsku analizu i prijedloge praktičnih modela v. u: Stanley, Guru i Gupta 2018. 
u protuterorističkom kompleksu. Repozicioniranje socijalnih službi u kontekstu suočavanja s rizicima vodi k redukcionističkoj i prinudnoj ulozi, pri čemu je narušena ravnoteža u korist orijentacije na rizik i na štetu orijentacije na dobrobit.

Socijalne službe kao protuteroristički akteri prema britanskima strateškim i zakonskim određenjima imaju, dakle, zadataću detektirati i identificirati pojedince koji su podložni riziku radikalizacije, procijeniti rizik moguće radikalizacije i dati im potporu kako ne bi postali teroristi odnosno podržavatelji terorizma. Time je socijalnim službama dodijeljena obveza obavještajnog djelovanja. Obavještajno djelovanje nesporno je jedan od najznačajnijih protuterorističkih instrumenata. Upravo informacije i na njima izrađene analize kao rezultat obavještajnog djelovanja trebaju državi dati "prethodno znanje" i sposobnost predviđanja terorističkih prijetnji i mogućnosti da pojedinci postanu teroristi. Pritom je djelovanje usmjereno i na stratešku i na taktičku razinu, što podrazumijeva obavještajna istraživanja mikrodruštvenih grupacija, stanovitih društvenih enklava, iz kojih mogu doći terorističke prijetnje.

Drugim riječima, efikasna protuteroristička strategija podrazumijeva obavještajne informacije o "domaćim teroristima" ili, šire promatrano, informacije o društvenoj zajednici (community intelligence) (O'Brien 2009). Refokusiranje i reorijentacija obavještajnog djelovanja u protuterorizmu uvjetovali su to da su, prema svojemu profesionalnom poslanju, državni akteri u protuterorističkim djelovanjima i procesima deradikalizacije potencijalnih terorista postale i socijalne službe. Obavještajno djelovanje na socijalno-kulturnom području (sociocultural intelligence), odnosno analiza etničkih, socijalnih, kulturnih i demografskih podataka, omogućuje shvaćanja kulturoloških, bi- hevioralnih i operativnih obilježja terorističke organizacije i procesa stvaranja terorista. Socijalno-kulturno obavještajno djelovanje adresirano je na obavještajne informacije koje donositeljima odluka daju znanje kao podlogu za djelovanje s obzirom na preferencije, ideologije, ponašanje, afilijacije i percepcije pojedinaca i grupacija (Tomes 2015; Guidere 2012; Patton 2010). Drugim riječima, stvaraju se znanje o procesu radikalizacije i podloga za intervenciju u taj proces, što i jest cilj deradikalizacije. Podređivanje socijalnog rada logici sigurnosti time je postalo očitim. Socijalne službe usmjerene su na rizične grupacije, ponajprije muslimansku. One trebaju prikupljati podatke o namjerama i akcijama rizičnih osoba, mogućnostima da se radikaliziraju i postanu teroristi te anticipirati njihovo buduće ponašanje. Time dominantno preuzimaju funkciju "nadzornika" koji kontrolira ljude $\mathrm{u}$ interesu sigurnosti društvenog poretka. Sigurnost društva dominira nad socijalnom rehabilitacijom radikaliziranih isključenih pojedinaca. Višestruke su implikacije takve uloge socijalnog rada (Finch i McKendrick 2019; McKendrick i Finch 2017). Profesionalno-etički aspekt nameće pitanje o povjerljivosti odnosa i međusobnog povjerenja socijalnih radnika i korisnika socijalnih usluga. Socijalni radnici nisu imuni na političko-sigurnosno okruženje u kojemu djeluju. Rat protiv terora, politika straha, islamofobija i teroristička suspektnost muslimanske zajednice itekako utječu na socijalne radnike ${ }^{9}$ i

\footnotetext{
9 Neki slučajevi izvan standardnih profesionalnih odnosa posebno su zanimljivi. Nakon policijskog postupanja zbog napada panike i depresije pod tretmanom zdravstveno-socijalne skrbi u Britaniji bila je supruga Mohammada Sidiquea Khana, britanskog državljanina pakistanskog podrijetla, jednoga od četverice bombaša samoubojica koji su izveli teroristički udar u Londonu u srpnju 2005. Britanac iračkog podrijetla, doktor medicine Bilal Abdulla, i
} 
korisnike socijalnih usluga. ${ }^{10}$ Još je ozbiljnije pitanje sposobnost socijalnih radnika da obavljaju obavještajne poslove. Studije terorizma dokazuju da ne postoji ni jedinstven profil terorista ni jedinstven faktor koji služi kao prediktor za utvrđivanje tko postaje terorist ili koja kombinacija različitih faktora i njihov uzročni odnos vode $\mathrm{k}$ terorizmu (Horgan 2014). Stoga je važno znati na temelju kojega modela socijalni radnici utvrđuju tko postaje terorist.

Drugi aspekt strategije prevencije terorizma i deradikalizacije jest društvena reintegracija radikaliziranih osoba. ${ }^{11} \mathrm{U}$ konkretnom slučaju to podrazumijeva promociju i prihvaćanje britanskih vrijednosti. Posredstvom ideoloških protuterorističkih i deradikalizacijskih narativa nastoje se osvojiti "srce i duša" radikaliziranih osoba, odnosno onemogućiti utjecaj ideologije terorizma i utjecaj uzroka nezadovoljstva koji vode $\mathrm{k}$ terorizmu. Britanski muslimani ciljana su meta tih strateških komunikacijskih operacija (Ragazzi 2016; Mythen, Walklate i Peatfield 2017; Sabir 2017; Choudhury 2017; Jarvis i Lister 2017). U paradigmi komunitarizma, socijalne i građanske vrijednosti iznad su osobnih, a jačanjem zajednice nastoje se prevenirati socijalna izolacija i otuđenje, što je temelj socijalne stabilnosti i kohezije (Etzioni 1998). Pristup osvajanja "srca

indijski musliman, Kafeed Ahmed, doktor informacijskih znanosti, zaposlenici britanskog National Health Servicea, izveli su neuspješne napade automobilskom bombom u Londonu i na aerodromu u Glasgowu 2007.

${ }^{10} \mathrm{O}$ sekuritizaciji sektora socijalnih usluga govori i činjenica da je Europski sud pravde u postupku M and Others $v$ Her Majesty's Treasury iz 2010. presudio da se članovima obitelji sumnjivih terorista ne mogu uskratiti prava socijalne sigurnosti (O’Brien 2016: 205).

11 U protuterorističkim strategijama u pojedinim državama taj se model, koji uključuje različite tehnike, naziva i socijalnom reinsertacijom (Altier, Thoroughgood i Horgan 2014; Geipel 2007). i duše" u središtu strategija prevencije podrazumijeva uvođenje presudnih elemenata protupobunjeničkih (vojnih) tehnika (COIN) (Kienscherf 2011) u britansko društvo i unutarnje političke odnose. I u tom slučaju uloga socijalnog rada podređena je sigurnosnoj logici. Stavljanjem socijalnih službi u status protuterorističkoga i protupobunjeničkog subjekta i širenjem njihove uloge i funkcija izbrisana je granica između socijalnih i sigurnosnih politika.

Naposljetku, tradicionalna funkcija socijalnog rada usmjerena je na dobrobit potrebitih. Usmjerena je na socijalnu pravednost, promociju boljega i pravednijeg društva i društva jednakosti. Cilj je politike i prakse socijalnog rada osigurati blagostanje (welfare safeguarding). Uvođenjem socijalnog rada u protuterorizam naglasak se pomiče na rizik, djelovanje prije počinjenja kaznenog djela od strane potencijalnih terorista, kontrolnu funkciju potencijalno ugrožavajućeg ponašanja, čime se bitno podrivaju temelji pravednosti. Sekuritizacijom terorizma sekuritizirana je i praksa socijalnog rada s ciljem sprečavanja terorizma. Uloga socijalnog rada time je usmjerena na ostvarenje sekuritizacije (securitised safeguarding) i sekuritizaciju blagostanja (securitised welfare) (Finch i McKendrick 2019; McKendrick i Finch 2017; McCulloch i Pickering 2009).

\section{Zaključak: je li socijalni rad instrument nacionalne sigurnosti?}

Studije sigurnosti ne zadovoljavaju potpuno sve uvjete koje sociolozi znanosti smatraju nužnima da bi se ustanovilo neko znanstveno polje. Granice između njih i drugih studija u društvenim znanostima nisu čvrsto određene pa postoje mnoge "granične zone" i preklapanja s drugim znanstvenim disciplinama. Stoga ih se promatra kao znanstveno područje $\mathrm{u}$ liminalnom statusu. Kao poluinstitu- 
cionalizirana znanstvena poddisciplina, studije sigurnosti imaju dvostruk identitet. One su akademsko područje i relevantne su za provedbenu politiku. Orijentiranost na provedbenu politiku podrazumijeva stvaranje i primjenu znanja korisnog za državu i državnu politiku. Unatoč promjenama, proširenju i produbljenju, sigurnosne studije teorijski još nisu uključile socijalnu sigurnost. Empirijski argumenti izloženi u radu ukazuju na potrebu preispitivanja takva stajališta. U eri sekuritizacije terorizma od početka 21. stoljeća, a posebice zbog sve veće multidimenzionalnosti terorizma, preklapaju se i umrežavaju različite politike, procesi i akteri te postupno brišu granice između socijalnih i sigurnosnih politika. Socijalne službe i socijalni rad koji se prakticiraju u protuterorističkim djelovanjima podređeni su logici sigurnosti. Postali su relevantnima protuterorističkim subjektima i instrumentima u obavještajnim istraživanjima procesa radikalizacije potencijalnih terorista. U ostvarenju misije poboljšanja kvalitete života pojedinaca i razvoja potencijala potrebitih osoba, uz adresiranje prepreka, nepravdi i nejednakosti u društvu, temelji su socijalnog rada načela ljudskih prava i socijalne pravde. No naglašeni pomak od funkcije profesionalnih skrbnika potrebitih $\mathrm{k}$ funkciji "nadzornika" koji kontroliraju ljude u interesu društvenog poretka i sigurnosti društva daje socijalnom radu drugačiju ulogu. Nasilni politički konflikt neizbježno utječe na socijalni rad, socijalne radnike i korisnike socijalnih usluga.

U eri eskalacije terorizma i programa deradikalizacije terorizma, korisnici su usluga "oni drugi", potencijalni teroristi, demonizirani i percipirani kao društveno opasni. Socijalni rad usmjeren je na njihovu deradikalizaciju i odvraćanje od terorizma. Usmjeren je na obavještajno istraživanje i obavještajne procjene potencijalnih terorista. Treba spoznati ideologiju i namjere radikaliziranih osoba kako bi se spriječila radikalizacija i jačala socijalna kohezija. Redefiniranje uloge socijalnog rada još je jedan u nizu dokaza moći i utjecaja terorizma. Efikasna strategija protiv terorizma jest ona koja eliminira bilo kakve terorističke prijetnje. Protuterorističke strategije u konačnici ne uključuju samo oružano uništenje terorističkih mreža, uhićenja i kaznena procesuiranja, likvidacije pripadnika terorističkih organizacija ili sprečavanje izvršenja terorističkih akata. Koncept protuterorizma nameće državama i međunarodnoj zajednici obvezu stvaranja uvjeta koji grade uvjerenje da su sposobni ostvariti zadovoljavajući stupanj sigurnosti stanovništva i društvene zajednice, da su sposobni uvjerljivo ukloniti buduće terorističke prijetnje te obeshrabriti sve one koji u budućnosti namjeravaju podržati teroriste.

Suvremeni događaji jasno pokazuju da zapadne demokracije ne mogu efikasno riješiti pitanje terorizma a da se ne odreknu dijela svojih temeljnih vrijednosti. Je li već ta činjenica stanovit uspjeh terorističkih organizacija? Bez obzira na definirane krajnje ciljeve, jedan od međufaznih ciljeva terorističkih organizacija jest destabilizacija političkog sustava ciljane države. Odricanje od usvojenih i primijenjenih temeljnih vrijednosti i redovitoga državnog funkcioniranja zasigurno znače određenu destabilizaciju konkretne države. Izvanredne mjere postaju trajnom normom, a abnormalnost se prihvaća kao normalnost. Izvorna orijentacija socijalnog rada i socijalnih službi na dobrobit još postoji, ali su izrazito promijenjene okolnosti u kojima se suočavaju s novim izazovima sigurnosne provenijencije. Drugim riječima, orijentacija na rizik preteže nad orijentacijom na dobrobit. To je okvir u kojemu su socijalne službe postali obavještajni subjekti u eri sekuritizacije terorizma, a socijalni rad obavještajni instrument u protuterorističkim strategijama zapadnih demokracija. 


\section{Literatura}

Altier, Mary B., Thoroughgood, Christian N., Horgan, John G. 2014. Turning a way from terrorism: Lessons from psychology, sociology, and criminology. Journal of Peace Research. (51) 5: 647-661. DOI: $10.1177 / 0022343314535946$

Awan, Imran. 2012. 'I'm a Muslim not an extremist': how the Prevent strategy has constructed a 'suspect' community. Politics \& Policy. (40) 6: 11581185. DOI: 10.1111/j.1747-1346.2012. 00397.x

Agamben, Giorgio. 2008. Izvanredno stanje: Homo sacer, II, 1. Zagreb: Deltakont.

Abualola, Turky. 2013. Social Services In the Field of Terrorism. Kindle Book. Xlibris LLC.

Banks, Sarah. 1995. Ethics and Values in Social Work. Houndmills i London: MacMillan Press.

Barsky, Allan E. 2010. Ethics and Values in Social Work. An Integrated Approach for a Comprehensive Curriculum. Oxford: Oxford University Press.

Baum, Nehami, Ramon, Shulamit. 2010. Professional growth in turbulent times: an impact of political violence on social work in Israel. Journal of Social Work. (10) 2: 139-156. DOI: 10.1177/1468017310363636

Bežovan, Gojko, Matković, Teo, Puljiz, Vlado, Šućur, Zoran, Zrinščak, Siniša. 2005. Pojmovnik socijalne politike. U: Puljiz, Vlado, Bežovan, Gojko, Šućur, Zoran, Zrinščak, Siniša. (ur.). Socijalna politika: povijest, sustavi, pojmovnik. Zagreb: Pravni fakultet Sveučilišta u Zagrebu, str. 425-475.

Bilandžić, Mirko. 2017. Socijalna politika (sigurnost) kao područje nacionalne sigurnosti: prilog raspravi o kritičkim sigurnosnim studijama. Revija za socijalnu politiku. (24) 3: 343-359. DOI: $10.3935 /$ rsp.v24i3.1419
Bilandžić, Mirko. 2014. Sjeme zla. Uvod u studije terorizma. Zagreb: Despot infinitus i Filozofski fakultet Sveučilišta u Zagrebu.

Bilandžić, Mirko. 2005. Sjeverna Irska između rata $i$ mira. Zagreb: Golden marketing-Tehnička knjiga.

Bjorgo, Tore. (ur.). 2005. Root Causes of Terrorism: Myths, reality and ways forward. Abingdon i New York: Routledge.

Bourbeau, Philippe. (ur.). 2015. Security: Dialogue across Disciplines. Cambridge: Cambridge University Press.

Bourbeau, Philippe 2015a. A multidisciplinary dialogue on security. U: Bourbeau, Philippe. (ur.). Security: Dialogue across Disciplines. Cambridge: Cambridge University Press, str. 1-21.

Bourbeau, Philippe, Balzacq, Thierry, Cavelty, Myriam D. 2015. International relations: Celebrating eclectic dynamism in security studies. U: Bourbeau, Philippe. (ur.). Security: Dialogue across Disciplines. Cambridge: Cambridge University Press, str. 111136.

Buzan, Barry. 1991. People, States and Fear: An agenda for International Security Studies in the Post-Cold War Era. London: Harvester Wheatsheaf.

Buzan, Barry, Hansen, Lene. 2009. The Evolution of International Security Studies. Cambridge: Cambridge University Press.

Buzan, Barry, Waever, Ole, De Wilde, Jaap. 1998. Security: A New Framework for Analysis. Boulder: Lynne Reiner.

Campbell, Jim, McCrystal, Patrick 2005. Mental health social work and the Troubles in Northern Ireland: A study of practitioner experiences. Journal of Social Work. (5) 2: 173-189. DOI: $10.1177 / 1468017305054971$ 
Choudhury, Tufyal 2017. The radicalisation of citizenship deprivation. Critical Social Policy. (37) 2: 225-244. DOI: $10.1177 / 0261018316684507$

Collins, Alan. 2010. Uvod: Što su sigurnosne studije? U: Collins, Alan. (ur.). Suvremene sigurnosne studije. Zagreb: Centar za međunarodne i sigurnosne studije Fakulteta političkih znanosti Sveučilišta u Zagrebu i Politička kultura, str. 15-25.

Counter-Terrorism and Security Act. 2015. http://www.legislation.gov.uk/ ukpga/2015/6/ contents/ (pristupljeno 26. svibnja 2016).

Council of the European Union. 2005. The European Union Counter-Terrorism Strategy. https://register. consilium. europa.eu/doc/srv?l=EN\&f=ST\%20 14469\%202005\%20REV\%204 (pristupljeno 15. travnja 2010).

Cowden, Steven, Singh, Gurnam. 2017. Community cohesion, communitarianism and neoliberalism. Critical Social Policy. (37) 2: 268-286. DOI: $10.1177 / 0261018316670252$

Day, Peter R. 1979. Care and Control: A Social Work Dilemma. Social Policy \& Administration. (13) 3: 206-209. DOI: 10.1111/j.1467-9515.1979.tb00657.x

Delivet, Philippe. 2016. The European Union and the fight to counter terrorism. Fondation-Robert Schuman, Policy Paper. European Issues. N³86. https://www.robert-schuman.eu/en/ doc/questions-d-europe/qe-386-en. pdf (pristupljeno 26. svibnja 2017).

Erlenbusch, Verena. 2014. How (not) to study terrorism. Critical Review of International Social and Political Philosophy. (17) 4: 470-491. DOI: $10.1080 / 13698230.2013 .767040$

Etzioni, Amatai. (ur.). 1998. The Essential Communitarian Reader. Lanham: Rowman \& Littlefield.

European Commission. 2015. European Agenda on Security. https://ec.europa. eu/anti-trafficking/sites/antitrafficking/files/eu_agenda_on_security_ en.pdf (pristupljeno 9. travnja 2016).

Evens, Phillip. 1973. Social Control and Values in Social Work. Probation Journal. (19) 1: 9-12. DOI: 10.1177/026455057301900103

Ewijk, Hans V. 2009. European Social Policy and Social Work. Citizenship-based Social Work. London i New York: Routledge.

Expert Group. 2008. Radicalisation Processes Leading to Acts of Terrorism: A Concise Report prepared by the European Commission's Expert Group on Violent Radicalisation. https:// biblio.ugent.be/publication/446365/ file/6814706 (pristupljeno 8. rujna 2009).

Finch, Jo, McKendrick, David. 2019. Securitising social work: Counterterrorism, extremism, and radicalisation. $\mathrm{U}$ : Webb, Stephen, A. (ur.). The Routledge Handbook of Critical Social Work. Oxon i New York: Routledge, str. 244255.

Foucault, Michel. 1977. Discipline and punish: The Birth of the Prison. New York: Vintage Books.

Franks, Jason. 2006. Rethinking the Roots of Terrorism. Basingstoke: Palgrave Macmillan.

Garland, David. 2001. The culture of control: Crime and social order in contemporary society. Oxford: Oxford University Press.

Garner, Geraldine. 2008. Careers in Social and Rehabilitation Services. Third Edition. New York: McGraw-Hill.

Geipel, Gary. 2007. Urban Terrorists in Continental Europe after 1970: Implications for Deterrence and Defeat of Violent Nonstate Actors. Comparative Strategy. (26) 5:439-467. DOI: $10.1080 / 01495930701750273$

Guidere, Mathieu. 2012. Novi teroristi. Zagreb: Alfa. 
Guru, Surinder. 2010. Social Work and the 'War on Terror'. British Journal of Social Work. (40) 1: 272-289. DOI: 10.1093/bjsw/bcn129

HM Government. 2015. Channel Duty Guidance: Protecting vulnerable people from being drawn into terrorism, Statutory guidance for Channel panel members and partners of local panels. https:// assets.publishing.service.gov.uk/government/uploads/system/ uploads/attachment_data/file/425189/Channel_ Duty_Guidance_April_2015.pdf (pristupljeno 8. rujna 2018).

HM Government. 2012. Channel: Vulnerability Assessment Framework. https: // www.gov.uk/government/uploads/ system/uploads/attachment_data/ file/118187/vul-assessment.pdf (pristupljeno 12. listopada 2014).

HM Government. 2011. Contest: The United Kingdom's Strategy for Countering Terrorism, Norwich: TSO (The Stationery Office). https://www.counterextremism.org/ resources/details/ $\mathrm{id} / 277 /$ contest-the-united-kingdom (pristupljeno 12. listopada 2014).

HM Government. 2011a. Prevent Strategy. https://www.gov.uk/government// publications/prevent-strategy-2011 (pristupljeno 12. listopada 2014).

Herington, Jonathan. 2015. Philosophy: The concepts of security, fear, liberty, and the state. U: Bourbeau, Philippe. (ur.). Security: Dialogue across Disciplines. Cambridge: Cambridge University Press, str. 22-44.

Home Office. 2018. Individuals referred to and supported through the Prevent Programme. Statistical Bulletin, 31/18. https://assets.publishing.service.gov.uk/ government/ uploads/system/uploads/attachment_ data/file/763254/individuals-referred-supported-prevent-programme-apr2017-mar2018-hosb3118.pdf (pristupljeno 2. ožujka 2019).
Horgan, John. 2014. The psychology of terrorism. New York: Routledge.

Horgan, John. 2008. Deradicalization or Disengagement? A Process in Need of Clarity and a Counterterrorism Initiative in Need of Evaluation. Perspectives on Terrorism. (4) 2: 3-8. DOI: 10.1174/021347409788041408

Horgan, John, Altier, Mary B. 2012. The Future of Terrorist De-Radicalization Programs. Georgetown Journal of International Affairs. (13) 2: 83-90.

International Federation of Social Workers (IFSW). 2014. Global Definition of Social Work. http://ifsw.org/policies/ definition-of-social-work/ (pristupljeno 10. srpnja 2017).

Ivanauskiene, Violeta, Makštutyte, Ramune. 2012. Terrorism: Implications for International Social Work. Tiltai. (59) 2: 59-69.

Itzhaky, Haya, York, Alan S. 2005. The role of the social worker in the face of terrorism: Israeli community-based experience. Social Work. (50) 2: 141149.

Jarvis, Lee, Lister, Martin. 2017. 'As a woman...'; 'As a Muslim...': Subjects, positions and counterterrorism powers in the United Kingdom. Critical Social Policy. (37) 2: 245-267.

Kemshall, Hazel. 2013. Risk Assessment and Risk Management. U: Davies, Martin. (ur.). The Blackwell Companion to Social Work. Fourth Edition. Chichester: Wiley-Blackwell, str. 333343.

Khosrokhavar, Farhad. 2017. Radikalizacija. Zagreb: TIM press.

Kienscherf, Markus. 2011. A programme of global pacification: US counterinsurgency doctrine and the biopolitics of human (in)security. Security Dialogue. (42) 6: 517-535. DOI: $10.1177 / 0967010611423268$

Knudsen, Rita A. 2018. Measuring radicalisation: risk assessment conceptu- 
alisations and practice in England and Wales. Behavioral Sciences of Terrorism and Political Aggression. DOI: 10.1080/19434472.2018.1509105.

Kundani, Arun. 2015. The Muslims are coming: Islamophobia, extremism and the domestic war on terror. New York: Verso.

Lorenz, Walter. 1994. Social Work in a Changing Europe. London: Routledge.

Lucić, Danijela. 2017. Terorizam kao oblik državnoga djelovanja - izmedu normativnoga $i$ empirijskoga. Doktorski rad. Zagreb: Fakultet političkih znanosti Sveučilišta u Zagrebu.

Malik, Shanin. 2015. Constructing security. U: Hough, Peter, Malik, Shahin, Roberts, Andrew, Pilbeam, Bruce. (ur.). International Security Studies: Theory and practice. New York i Abingdon: Routledge, str. 72-84.

McCulloch, Jude, Pickering, Sharon. 2009. Pre-crime and counter-terrorism: imagining future crime in the 'war on terror'. British Journal of Criminology. (49) 5: 628-645. DOI: 10.1093/ bjc/azp023

McKendrick, David, Finch, Jo. 2017. 'Downpressor man': securitisation, safeguarding and social work. Critical and Radical Social Work. (5) 3: 287300. DOI: $10.1332 / 204986017 \mathrm{X} 1502$ 9697482460

Mirahmadi, Hedieh. 2016. Building Resilience against Violent Extremism: A Community-Based Approach. The ANNALS of the American Academy of Political and Social Science. (668) 1:129144. DOI: $10.1177 / 0002716216671303$

Mullins, Sam. 2016. 'Home-Grown' Jihad: Understanding Islamist Terrorism in US and UK. London: Imperial College Press.

Mythen, Gabe, Walklate, Sandra, Peatfield, Elizabeth, J. 2017. Assembling and deconstructing radicalisation in PREVENT: A case of policy-ba- sed evidence making? Critical Social Policy. (37) 2: 180-201. DOI: $10.1177 / 0261018316683463$

National Association of Social Workers (NASW). 2008. Code of Ethics of the National Association of Social Workers. https://www.socialworkers.org/About/ Ethics/Code-of-Ethics/Code-of-Ethics-English (pristupljeno 11. srpnja 2017).

O'Brien, Peter. 2016. The Muslim Question in Europe: Political Controversies and Public Philosophies. Philadelphia, Rim i Tokio: Temple University Press.

O'Brien, Kevin A. 2009. Managing national security and law enforcement intelligence in a globalised world. Review of International Studies. (35) 4: 903-915. DOI: 10.1017/ S0260210509990349

Parrott, Lester. 2010. Values and Ethics in Social Work Practice. Second Edition. Exeter: Learning Matters.

Patton, Kerry. 2010. Socio-Cultural Intelligence: A New Discipline in Intelligence Studies, New York: Bloomsbury.

Ragazzi, Francesco. 2016a. Suspect community or suspect category? The impact of counter-terrorism as 'policed multiculturalism'. Journal of Ethnic and Migration Studies. (42) 5: 724-741. DOI: 10.1080/1369183X.2015.1121807

Ragazzi, Francesco. 2016. Countering terrorism and radicalisation: Securitising social policy? Critical Social Policy. (37) 2: 1-17. DOI: $10.1177 / 0261018316683472$

Ramon, Shulamit, Campbell, Jim, Lindsay, Jane, McCrystal, Patrick, Baidoun, Naimeh. 2006. The impact of political conflict on social work: Experiences from Northern Ireland, Israel and Palestine. British Journal of Social Work. (36) 3: 435-450. DOI: 10.1093/ bjsw/bcl009

Radicalisation Awareness Network (RAN). 2017. Preventing Radicalisa- 
tion to Terrorism and Violent Extremism: Approaches and Practices. https:// ec.europa.eu/home-affairs/sites/homeaffairs/files/what-we-o/networks/ radicalisation_awareness_network/ ran-best-practices/docs/ran_collection-approaches_and practices_en.pdf (pristupljeno 23. rujna 2017).

Richards, Anthony. 2014. Conceptualizing Terrorism. Studies in Conflict \& Terrorism. (37) 3: 213-236. DOI: 10.1080/1057610X.2014.872023.

Richardson, Louise. (ur.). 2006. The Roots of Terrorism, New York and London: Routledge.

Ritter, Jessica A., Vakalahi, Halaevalu O. 2015. 101 Careers in Social Work. New York: Springer.

Sabir, Rizwaan. 2017. Blurred lines and false dichotomies: Integrating counterinsurgency into the UK's domestic 'war on terror'. Critical Social Policy. (37) 2: 202-224. DOI: $10.1177 / 0261018316683471$

Scotland Against Criminalising Communities (SACC). 2016. Whitehall releases 2003 Counter Terrorism Strategy. http://www.sacc.org.uk/press/2016/whitehall-releases-2003-counter-terrorism-strategy (pristupljeno 10. listopada 2017).

Schmid, Alex P. 2013. Radicalisation, De-Radicalisation, Counter-Radicalisation: A Conceptual Discussion and Literature Review, ICCT Research Paper. https://www.icct.nl/download/file/ ICCT-Schmid-Radicalisation-De-Radicalisation-Counter-Radicalisation-March-2013.pdf (pristupljeno 18. rujna 2015).

Schmid, Alex P. 2011. The Definition of Terrorism. U: Schmid, Alex P. (ur.). The Routledge Handbook of Terrorism Resarch. London i New York: Routledge, str. 39-98.

Sweifach, Jay, LaPorte, Heidi H., Linzer, Norman. 2010. Social work res- ponses to terrorism: Balancing ethics and responsibility. International Social Work. (53) 6: 822-835. DOI: 10.1177/0020872809360036

Stampnitzky, Lisa, Mattson, Greggor. 2015. Sociology: Security and insecurities. U: Bourbeau, Philippe. (ur.). Security: Dialogue across Disciplines. Cambridge: Cambridge University Press, str. 90-110.

Stampnitzky, Lisa. 2015. Problematic knowledge: How 'terrorism' resist expertise. In: Berling, Trine V., Bueger, Christian. (ur.). Security Expertise: Practice, Power, Responsibility. London i New York: Routledge, str. 158-171.

Stanley, Tony, Guru, Surinder, Gupta, Anna. 2018. Working with PREVENT: Social Work Options for Cases of 'Radicalisation Risk'. Practice: Social Work in Action. (30) 2: 131-146. DOI:10.1080/09503153.2017.1414176

Theiler, Tobias. 2010. Societal security. U: Cavelty, Myriam D., Mauer, Victor. (ur.). The Routledge Handbook of Security Studies. Abingdon i New York: Routledge, str. 105-114.

Tomes, Robert R. 2015. Socio-Cultural Intelligence and National Security. $\mathrm{Pa}$ rameters. (45) 2: 61-76.

Van Munster, Rens. 2005. Logics of Security: The Copenhagen School, Risk Management and the War on Terror. Political Science Publications. 10/2005. http://static.sdu.dk/ (pristupljeno 18. siječnja 2008).

Waever, Ole. 2015. The History and Social Structure of Security Studies as a Practico-Academic Field. U: Berling, Trine V., Bueger, Christian. (ur.). Security Expertise: Practice, Power, Responsibility. London i New York: Routledge, str. 76-106.

Waever, Ole. 2011. Politics, security, theory. Security Dialogue. 42 (4-5), 465480. 
Williams, Paul, D. 2008. Security Studies: An Introduction. U: Williams, Paul, D. (ur.). Security Studies: An Introduction. London i New York: Routledge, str. 1-12.
Wolfers, Arnold. 1962. National security as an ambiguous symbol. Political Science Quarterly. (67) 4: 481-502.

\title{
Social Work and Security Logic in the Era of Terrorism Securitization
}

\begin{abstract}
Social work is oriented towards improving the quality of life and developing the potentials of individuals, especially of vulnerable social groups, as well as adressing societal problems, risks, injustices and inequalities. Human rights and social justice constitute the fundamental principles of social work. In the terrorism securitization era, i.e. from the beginning of $21^{\text {st }}$ century, due to the growing multidimensionality of terrorism by which various policies, processes and actors overlap and network, boundaries between social and security policies have been gradually dissappearing. Departure from the professional care for vulnerable populations function towards the "surveillance" function, by which individuals are controled in the interest of preserving social order and security, puts social work in all its meanings in a different role. In counterterrorist action, social services and social work are becoming subordinated to the security logic. By analyzing the framework for introducing social work into counterterrorist status and the role of social services in counterterrorism it becomes clear that social work performs the function of a national security policy intelligence instrument in the counterterrorist strategies of Western democracies.
\end{abstract}

Key words social work, social services, securitization, counterterrorism, national security 